\title{
O CASAMENTO HOMOAFETIVO \\ NO BRASIL: AS VISÕES \\ PROCEDIMENTALISTA E \\ SUBSTANCIALISTA
}

\author{
BRAZILIAN HOMOAFFECTIVE MARRIAGE: PROCEDURAL AND \\ SUBSTANTIAL VISIONS
}

\section{EL CASAMIENTO HOMOAFECTIVO EN BRASIL: LAS VISIONES PROCEDIMENTALISTAS Y SUSTANCILISTAS}

\author{
Priscila Tinelli Pinheiro ${ }^{1}$ \\ Emanuel José Lopes Pepino \\ Alexandre de Castro Coura ${ }^{3}$
}

Licença CC BY:

Artigo distribuído sob os termos Creative Commons, permite uso e distribuição irrestrita em qualquer meio desde que o autor credite a fonte original.
Resumo: O presente estudo trata da atuação do Poder Judiciário a partir da transformação dos paradigmas estatais e sua correspondente influência na postura adotada pelo Poder Judiciário. Objetiva-se, neste sentido, delinear a atuação do Judiciário no contexto brasileiro a partir da questão da legitimidade de suas atuações. Em seguida, discutem-se as principais características das correntes doutrinárias procedimentalista e substancialista acerca da atividade jurisdicional. Por fim, analisam-se os argumentos utilizados, pelo Supremo Tribunal Federal, nas decisões ADPF n. 132 e ADI n. 4277 para permitir a equiparação das uniões homoafetivas àquelas compostas por casais heterossexuais. Como principais conclusões, destaca-se a atuação limítrofe que os magistrados podem ter para que não se utilizem do ativismo judicial como sinônimo de decisionismo e discricionariedade, tampouco abstenham-se de efetivar os direitos fundamentais em sua atividade judicante.

Palavras-chaves: Ativismo judicial; substancialismo; procedimentalismo; união homoafetiva.

1 Mestre e Doutoranda em Direitos e Garantias Fundamentais pela Faculdade de Direito de Vitória (FDV). Membro do Grupo de Pesquisa Invisibilidade Social e Energias Emancipatórias em Direitos Humanos (FDV). Advogada. E-mail: priscilatinelli@hotmail.com.

2 Doutorando em Direito pela FDV-ES, Mestre em Direito (Universidade de Coimbra). Membro do Grupo de Pesquisa CNPq “Teoria do Constitucionalismo”, da FDV-ES. Endereço eletrônico: e_pepino@hotmail.com.

3 Pós-doutorado como visiting scholar na American University e visiting foreign judicial fellow no Centro Judiciário Federal em Washington D.C. Doutor e Mestre em Direito Constitucional pela Universidade Federal de Minas Gerais (UFMG). Ex-professor efetivo de Direito Material e Processual Penal da Universidade Federal do Espírito Santo (UFES). Professor de Teoria dos Direitos Fundamentais no Programa de Mestrado e Doutorado da Faculdade de Direito de Vitória (FDV). 5• Promotor de Justiça Cível da Comarca da Serra/ES (Patrimônio público e defesa dos consumidores). E-mail: acastrocoura@gmail.com. 


\begin{abstract}
This study is related to the activity of the Judiciary, based on the transformation of state paradigms and their corresponding influence on the position adopted by the Judiciary. This work therefore gives a brief update of the Judiciary in the Brazilian context, based on the legitimacy of its actions. It is also discusses the main characteristics of the procedural and substantialist doctrinal visions in the judicial activity. Finally, it analyzes the arguments used by the Federal Supreme Court (ADPF 132 and ADI 4277), to draw a comparison between homoaffective and heterosexual unions. It concludes by highlighting the limits of the actions that magistrates may have, so that they do not use judicial activism as a synonym of decision and discretion, nor do they abstain from effecting fundamental rights in their judicial activity.
\end{abstract}

Keywords: Judicial activism; substantiality; procedimentalismo; homoaffective union.

Resumen: El presente estudio trata de la actuación del Poder Judiciario a partir de la transformación de los paradigmas estatales y su correspondiente influencia en la postura adoptada por el Poder Judiciario. Se objetiva, en este sentido, delinear la actuación del Judiciario en el contexto brasileño a partir de la cuestión de la legitimidad de sus actuaciones. A continuación, se discuten las principales características de las corrientes doctrinarias procedimentalista y sustancialista acerca de la actividad jurisdiccional. Por fin, analizaremos los argumentos utilizados, por el Supremo Tribunal Federal, en las decisiones ADPF n. 132 ADI n. 4277 para permitir la equiparación de las uniones homoafectivas aquellas compuestas por parejas heterosexuales. Como principales conclusiones, se destaca la actuación limítrofe que los magistrados pueden tener para que no se utilicen el activismo judicial como sinónimo de determinación y discrecionalidad, y que tampoco se abstengan de efectivar los derechos fundamentales en su actividad judicante.

Palabras-clave: Activismo judicial; sustancialismo; procedimentalismo; unión homoafectiva.

INTRODUÇÃO

O grande desafio posto no atual panorama de um efetivo Estado Democrático de Direito é a superação, pelos que compõem o Poder Judiciário, das práticas desenvolvidas nos paradigmas dos Estados Liberal e de Bem-Estar Social. Isso porque a forma pela qual as decisões provenientes da esfera judicial eram tomadas se apresentam como insuficientes diante de tamanha complexidade atingida pelas relações sociais contemporâneas.

No primeiro modelo de Estado, havia a prevalência da típica subsunção do fato à norma, a qual configura a interpretação mais básica da legislação: a literal ${ }^{4}$. Neste modelo, prevalecia a postura passiva do juiz, que não intervinha

4 Reconhecendo a importância da virada linguística e da inexistência de um significado dentro do texto, está se usando a terminologia literal para indicar o posicionamento de autores como Jean-Jacque Rousseau ou Jeremy Bentham, que afirmavam que a lei era clara e não cabia ao Judiciário interpretá-la (se esclarecimentos fossem necessários, deveriam vir do Legislativo, não do Judiciário). Nesse sentido, o mais próximo que se pode chegar de um sentido literal é o que Dworkin chama de interpretação acontextualizada (DWORKIN, Ronald. O Império 


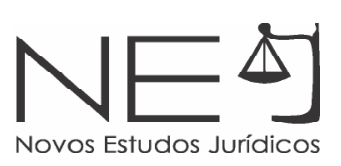

na esfera dos interesses privados. Não se nega a importância deste tipo de interpretação, contudo utilizá-la de maneira isolada é reduzir a figura do juiz num mero "boca da lei". No segundo modelo, o objetivo era alcançar a proposta social previamente delimitada pelo Estado, o que, por mais que represente certo avanço em relação àquela modalidade de interpretação, ainda é considerada limitada ante a impossibilidade de concretizar os direitos básicos da população.

Com a ascensão do Estado Democrático de Direito, faz-se fundamental ultrapassar as barreiras criadas pelos arquétipos anteriores e rediscutir a atividade jurisdicional em busca de maior legitimidade das suas decisões. Tornase necessário, então, ir além no sentido de agrupar as mais diversificadas formas interpretativas da lei, a fim do magistrado exercer sua capacidade criativa em busca da forma mais adequada de resolução da lide, que lhe é posta sob jurisdição.

É importante frisar que a atividade judicante não é fácil, tendo em vista o emaranhado de problemas jurídicos construídos com base nos conflitos sociais, cuja velocidade de evolução é muito superior do que qualquer capacidade legislativa consegue acompanhar. Apesar da necessidade de repensar a atividade jurisdicional, não se pode cair no risco de autorizar qualquer decisão do Judiciário como válida. O Direito não é, nem pode ser, apenas o que os tribunais dizem. Daí se faz mister estipular limites para a atuação do Judiciário, sob o risco de se viver em uma ditadura do Judiciário, que acaba tomando decisões centrais para o governo do país sem possuir uma legitimidade democrática para tanto.

Tentando responder a essa tensão latente entre a necessidade de possuir uma legitimidade democrática e de materializar direitos fundamentais, duas correntes doutrinárias distintas despontam: os substancialistas e os procedimentalistas. O objetivo geral deste trabalho é comparar as duas posições, buscando seus fundamentos principais. Como objetivos específicos, destaca-se a análise acerca da legitimidade da atuação do Judiciário brasileiro, no exemplo privilegiado, da questão do casamento de pessoas do mesmo sexo no Brasil por meio dos argumentos utilizados nas decisões ADPF n. 132 e ADI n. 4277, pelo Supremo Tribunal Federal, que permitiu a equiparação das uniões homoafetivas àquelas compostas por casais heterossexuais.

do Direito. Tradução de Jeferson Luiz Camargo. 3. ed. São Paulo: Martins Fontes, 2014. p. 22). 
À guisa de conclusão, magistrados que busquem fugir da utilização do ativismo judicial como decisionismo e discricionariedade, mas busquem realizar os direitos fundamentais em sua atividade judicante, acabam presos a uma atuação limítrofe, dada a dificuldade de sobrepesar esses limites.

\section{A ATUAÇÃO DO PODER JUDICIÁRIO E A QUESTÃO DA LEGITIMIDADE}

A feição assumida pelo Judiciário é construída a partir do paradigma vigente, seja o Estado Liberal, o Social, ou mesmo o Democrático de Direito, o que constitui reflexo do contexto histórico presente em cada um deles, uma vez que "[...] toda interpretação se dá sob a ótica de um determinado paradigma, sendo impossível ao intérprete se desvencilhar deste conjunto de precompreensões no qual está inserido"5.

Por outro lado, isso não significa que, construído um paradigma subsequente, o anterior é por completo abandonado. Isto é, não se deve pensar numa completa ruptura entre eles, pois - nos dizeres de Thomas Kuhn ${ }^{6}$ - entendese por paradigmas, "[...] as realizações científicas universalmente reconhecidas que, durante algum tempo, fornecem problemas e soluções modelares para uma comunidade de praticantes de uma ciência".

Há, nesta medida, "acumulação" entre o que vigorou em cada um deles, de modo que seja construída uma melhor forma de interpretação jurisdicional, o que pode não representar - contudo - um avanço significativo ao se comparar os referidos modelos. O que se faz necessário é, além de outros pontos, adequar os modelos interpretativos ao contexto do Estado Democrático de Direito, no qual se prima pela efetivação dos direitos fundamentais e, por isso, não comporta uma interpretação literal estanque - como aquela típica de um Estado abstencionista, como o Liberal -, tampouco uma aplicação legislativa que se reduza aos fins objetivados pelo Estado, quando estes não representam as necessidades dos cidadãos sob sua égide - característica de uma postura, de certa forma, intervencionista, como a adotada pelo Estado Social ou de Bem-Estar Social.

5 COSTA, Renata Pereira Carvalho; COURA, Alexandre de Castro. A atuação do magistrado e sua conformação paradigmática: o desafio de materializar o Estado Democrático de Direito, DPU, n. 32, p. 23-41, mar.-abril, 2010. p. 25.

6 KUHN, Thomas S. A estrutura das revoluções científicas. Tradução Beatriz Vianna Boeira e Nelson Boeira. 6. ed. São Paulo: Perspectiva, 2001. p. 13. 
Está posta, então, uma das grandes tensões com que o paradigma da modernidade deve lidar: democracia e constitucionalismo, que é instituída pela ausência de identificação entre os preceitos constitucionais e a vontade do povo. Logo, a existência de uma Carta Constitucional, contendo em seu bojo diversos direitos, não implica necessariamente o estabelecimento de uma democracia, visto que o seu elemento substancial é composto pela correspondência entre a atuação dos governantes e a vontade dos governados ${ }^{7}$. O grande dilema instituído é justamente encontrar uma forma constitucional vinculada ao princípio democrático, em que se estabelecessem limites, moderação, controle e legitimação do poder por seu titular - o povo - por meio da atuação dos seus representantes.

Já em relação ao exercício jurisdicional, no âmbito do Estado Democrático de Direito, destaca-se que - apesar de se permitir uma interpretação ampla - não significa que ela possa ser utilizada de maneira discricionária pelo magistrado, pois há uma limitação, representada pelos interesses dos jurisdicionados, a fim de conferir segurança jurídica aos mesmos - que é princípio democrático. Assim, ao juiz não se autoriza o emprego, por exemplo, "[...] de argumentos alienígenas ao Ordenamento Jurídico para sustentar suas decisões" ${ }^{\prime}$.

Esta tensão é reforçada pelos limites que, tanto a democracia quanto o constitucionalismo devem observar, no sentido de que

Se a democracia significa o povo decidindo as questões politicamente relevantes da sua comunidade, isso inclui os conteúdos da constituição de um país, isto é, normas que organizam as instituições do governo e estabelecem limites aos respectivos poderes governamentais. Entretanto, se o constitucionalismo significa limites à soberania popular, então alguns conteúdos da Constituição [...] devem permanecer fora do alcance da decisão majoritária ou das deliberações democráticas ${ }^{9}$.

Ao compreender, por um lado, a democracia como uma maneira de incluir os sujeitos de direitos nas discussões políticas e, por outro, o constitucionalismo como um regulamentador que instituiu os procedimentos que devem ser

7 MOUFFE, Chantal. Pensando a democracia moderna com e contra Carl Schimitt. Cadernos da Escola do Legislativo. Tradução de Menelick de Carvalho Netto. Belo Horizonte, n. 02, p.01-14, jul./dez., 1994.

8 COSTA, Renata Pereira Carvalho; COURA, Alexandre de Castro. A atuação do magistrado e sua conformação paradigmática: o desafio de materializar o Estado Democrático de Direito. p. 36.

9 CHUERI, Vera Karam de; GODOY, Miguel. Constitucionalismo e Democracia - Soberania e Poder Constituinte. Revista DireitoGV, v. 6, n. 1, p. 159-174, jan.-jun., 2010. p. 160. 
observados nesta inclusão, por vezes, haverá certos obstáculos ao pleno ${ }^{10}$ exercício da democracia. Obstáculos como a exclusão de grupos sociais interessados nas demandas, que não são reconhecidos - dentre a criação de diretrizes constitucionais - pelo constitucionalismo ${ }^{11}$.

A grande questão que precisa ser discutida gira em torno da suficiência ou não do procedimento democrático para garantir que uma decisão seja, ao mesmo tempo, correta e justa para o jurisdicionado. Isso porque, quando se pensa - por exemplo - na democracia representativa, que é o modelo adotado pelo sistema político brasileiro, Barbosa e Kozocki ${ }^{12}$ salientam que,

[...] apesar do voto majoritário ser considerado pedra fundamental no sistema da democracia representativa, o mesmo não é suficiente para garantir decisões corretas ou mesmo resultados justos e racionais, uma vez que o princípio majoritário não assegura a igualdade política. Ou seja, o resultado do voto majoritário representa a voz dos vencedores e não necessariamente o bem-comum ou o interesse de todos [...].

Com base nesta ressalva, identifica-se a dificuldade encontrada para se compatibilizar os interesses dos múltiplos grupos formadores de uma sociedade plural como a do Brasil. Na prática, verifica-se que é recorrente a prevalência de dos interesses de grupos mais "fortes", ou seja, mais bem representados na seara legislativa; os mais "fracos", do ponto de vista da representação acabam, neste sentido, prejudicados pela organização do sistema.

Cabe, neste sentido, ao Poder Judiciário, exercer sua função de maneira a possibilitar o equilíbrio - por meio da solução das demandas que lhes são postas sob análise e da consequente efetivação dos direitos fundamentais entre democracia e constitucionalismo. A tensão protagonizada por ambos, por sua vez, não deixará de existir - já que é o principal fundamento do modelo estatal contemporâneo -, devendo ser compreendida, de acordo com Chueri e Godoy ${ }^{13}$, como um sinal vigoroso no sentido de uma esfera pública radicalmente

10 A utilização do termo "pleno" diz respeito ao fato de haver decisões que o povo, mesmo querendo, não pode tomar, como a questão da pena de morte ou a liberação da tortura, tendo em vista os princípios instituídos pelo próprio texto constitucional.

11 CHUERI, Vera Karam de; GODOY, Miguel. Constitucionalismo e Democracia - Soberania e Poder Constituinte. p. 171.

12 BARBOSA, Estefânia Maria de Queiroz; KOZOCKI, Katya. Jurisdição constitucional brasileira: entre constitucionalismo e democracia. Revista Sequência, n. 56, p. 151-176, jun. 2008. p. 152.

13 CHUERI, Vera Karam de; GODOY, Miguel. Constitucionalismo e Democracia - Soberania e Poder Constituinte. p. 145. 
democrática.

Não se permite, entretanto, que o ato de decidir esteja fundamentado em meros subjetivismos jurisdicionais e nem que o juiz decida determinado caso concreto conforme a sua consciência, pois

\begin{abstract}
A Justiça não é nem deve ser o filtro de valores e de concepções morais identificados numa dada comunidade. A instância competente para tanto seria o Legislativo, no qual o procedimento é o mais democrático possível e a lei é concebida como fruto da vontade geral, manifestada pelos representantes eleitos de um povo soberano ${ }^{14}$.
\end{abstract}

Evita-se, desta maneira, que os interesses dos jurisdicionados sejam sobrepostos pelo livre arbítrio dos magistrados e desvirtue, sobremaneira, a ação do Poder Judiciário. Pois - por mais que se espere uma atitude criativa, em virtude do caráter transformador do Estado Democrático de Direito, no sentido de abandonar a passividade típica dos modelos anteriores de Estado - deve ser observado um mínimo de critérios possíveis, a fim de não transformar o protagonismo judicial num terreno obscuro legitimador de qualquer tipo de decisão, inclusive aquelas ilegítimas.

Não se espera, em contrapartida, que o Judiciário solucione todos os problemas sociais, mas tão somente que ele - no exercício de sua função jurisdicional - profira decisões que sejam ao mesmo tempo racionais, legítimas e justas, conforme se extrai do inciso XXXV, do artigo $5^{\circ}$ da Constituição Federal de 1988. O que, numa análise da elaboração do texto constitucional de 1988, infere-se que

[...] apesar de não excluir a importância do processo democrático, é uma constituição de valores e, por isso, estaria justificada a limitação dos Poderes Executivo e Legislativo pela jurisdição constitucional, bem como o ativismo judicial na definição e proteção dos valores escolhidos pela comunidade ${ }^{15}$.

É possível identificar práticas que inauguraram o ativismo judicial no Brasil, as quais se perfazem na mudança de interpretação do Supremo Tribunal Federal,

14 COSTA, Renata Pereira Carvalho; COURA, Alexandre de Castro. A atuação do magistrado e sua conformação paradigmática: o desafio de materializar o Estado Democrático de Direito. p. 37.

15 BARBOSA, Estefânia Maria de Queiroz; KOZOCKI, Katya. Jurisdição constitucional brasileira: entre constitucionalismo e democracia. p. 153. 
Novos Estudos Jurídicos

em 2007, por meio da resolução dos Mandados de Injunção n. 670, n. 708 e n. $712^{16}$, reconhecendo uma típica omissão legislativa - que é um dos fatores desencadeadores da prática ativista ${ }^{17}$-, motivou a decisão final do tribunal, por unanimidade, de aplicar subsidiariamente a legislação de greve referente aos trabalhadores do setor privado (Lei n. 7.783/89) ${ }^{18}$.

A questão central deixa de ser se o ativismo judicial é uma realidade ou não - ele é - e passa a ser em que momento uma decisão judicial, em nome da efetivação dos direitos fundamentais, extrapola os limites democráticos de decisão por parte do Judiciário. O aumento da submissão de demandas de cunho político ao Judiciário contribuiu para o alargamento da atuação deste poder e para o surgimento do fenômeno da "judicialização da política"19. Entretanto, é preciso compreender que o ativismo judicial está ligado a este fenômeno, o que não se confunde com o protagonismo judicial. O que se pretende evitar é uma supremacia do Poder Judiciário de forma a permitir que ele se coloque acima do próprio Direito. Logo, o problema não está no Poder Judiciário se colocar além da lei, porque isto a própria atividade hermenêutica já propicia, mas sim se sobrepor à lei, como uma atuação pautada em valores ou convicções pessoais.

Ao analisar esta expansão, Cittadino ${ }^{20}$ pondera a possibilidade de vislumbrar este fato como um reforço para a lógica democracia, na medida em que a ampliação do raio de atuação deste poder advindo do Estado não fere, na visão

16 Os Mandados de Injunção n. 670, n. 708 e n. 712 foram interpostos pelo Sindicato dos Servidores Policiais Civis do Estado do Espírito Santo (Sindpol), pelo Sindicato dos Trabalhadores em Educação do Município de João Pessoa (Sintem) e pelo Sindicato dos Trabalhadores do Poder Judiciário do Estado do Pará (Sinjep), respectivamente, os quais "[...] buscavam assegurar o direito de greve para seus filiados e reclamavam da omissão legislativa do Congresso Nacional em regulamentar a matéria, conforme determina o artigo 37, inciso VII, da Constituição Federal" (BRASIL. Supremo Tribunal Federal. Supremo determina aplicação da lei de greve dos trabalhadores privados aos servidores públicos. Disponível em: <http://www.stf.jus.br/portal/cms/ verNoticiaDetalhe.asp?idConteudo=75355>. Acesso em: 26 jun. 2017).

17 São considerados fatores que levam ao ativismo judicial: exercício do controle de constitucionalidade, existência de omissões legislativas e, por último, vagueza e ambiguidade do Direito.

18 BRASIL. Supremo Tribunal Federal. Supremo determina aplicação da lei de greve dos trabalhadores privados aos servidores públicos. $s / p$.

19 No que concerne a este fenômeno, Tassinari assevera que ele deve ser compreendido "[...] como um fenômeno circunstancial, porque decorrente de um contexto de fortalecimento da jurisdição no pós-Segunda Guerra Mundial, e, ao mesmo tempo, contingencial, no sentido de que o Judiciário é chamado a intervir pela inércia de algum dos outros Poderes do Estado, apresentando-se, portanto, muito mais como fruto de uma conjuntura político-social" (TASSINARI, Clarissa. Ativismo judicial: uma análise da atuação do Judiciário nas experiências brasileira e norte-americana. 2012. 141 fl. Dissertação (Mestrado em Direito na área das Ciências Jurídicas) - Universidade do Vale do Rio dos Sinos, São Leopoldo, 2012, p. 40, grifo da autora).

20 CITTADINO, Gisele. Poder Judiciário, ativismo judicial e democracia. Revista da Faculdade de Direito de Campos, v. 2, n. 3, p. 135-144, 2002. p. 136. 
da autora, a lógica da separação de poderes. Pelo contrário, deve-se ter em mente que a dimensão criativa da interpretação constitucional se faz presente em qualquer processo hermenêutico, sendo - por outro lado - imprescindível que, mesmo que ocorra uma transposição às legislações postas, os membros da esfera judicial devem primar pela construção de "decisões corretas" e pelo não envolvimento no exercício de "criação do direito" com base em valores ${ }^{21}$.

Fez-se necessária a modificação ocorrida no Judiciário, por meio da passagem de uma postura passiva, em que o juiz se restringia à subsunção do fato à norma, para uma postura ativa que pode padecer de certo grau de discricionariedade. No entanto, é preciso encontrar o equilíbrio para que não se retorne ao modelo clássico, o qual efetivamente não supre as demandas individuais da atualidade, haja vista tamanha complexidade atingida pelo entrelaçamento das relações sociais, bem como a incapacidade da legislação em acompanhar estas modificações, mas igualmente não se distorça a atividade jurisdicional mediante o abuso da autonomia adquirida pelo magistrado no Estado Democrático de Direito.

Por isso, é importante elencar-se critérios de forma a balizar a atividade judicante para que seja encontrada uma melhor solução possível para as demandas, na busca pela promoção dos direitos fundamentais. Não se pode, por um lado, conferir amarras que prendam o Judiciário ao que o Legislativo instituiu, tampouco permitir que sua autoridade competente estabeleça o que seja o Direito, pois isso extrapolaria suas funções.

É preciso, desta forma, criar "[...] condições para evitar que a jurisdição constitucional (ou o poder dos juízes) se sobreponha ao próprio direito. Parece evidente lembrar que o direito não é - e não pode ser - aquilo que os tribunais dizem que é"22. O problema ocorre não quando o Judiciário diz o que o Direito é, mas quando ele o faz sem um parâmetro mínimo de limites de atuação que, por sua vez, são diversos a depender da postura assumida pelos magistrados. O fato é que os critérios para esta criatividade, no sentido de não se restringir à interpretação literal, mas efetivamente proferir uma decisão justa, dependerá da teoria adotada, qual seja a procedimentalista ou a substancialista, as quais serão discutidas nos tópicos seguintes.

21 CITTADINO, Gisele. Poder Judiciário, ativismo judicial e democracia. p. 142.

22 MOREIRA, Nelson Camatta; TOVAR, Leonardo Zehuri. Ativismo judicial e resposta correta: análise crítica de fundamentos consequencialistas em Direito Tributário. Derecho y Cambio Social, v. 41, p. 1-16, 2015. p. 04. 


\section{PROCEDIMENTALISTAS “VERSUS” SUBSTANCIALISTAS: GRANDES DISTINÇÕES OU UM FALSO DILEMA?}

Neste segundo momento, serão apresentados os limites propostos pelos modelos procedimentalista e substancialista dentro do embate constitucional, a partir do que cada um deles preconiza para que, num terceiro momento, seja possível aplicar tais aspectos ao caso concreto referente às decisões que possibilitaram o reconhecimento, perante o ordenamento jurídico, do casamento entre pessoas do mesmo sexo.

Ressalta-se que as principais contribuições acerca do procedimentalismo serão apresentadas a partir da Teoria Discursiva de Jürgen Habermas, que é um grande expoente desta corrente, enquanto que as conjunturas do substancialismo serão pautadas nas construções teórica de Lenio Streck, que é um importante autor que dialoga com esta temática.

Dentro deste debate, a distinção entre as teorias mostra-se relevante quando se analisa a função desempenhada pela Constituição na sociedade e a extensão do exercício da jurisdição constitucional, sendo que esta última protagoniza, segundo Souza Neto e Sarmento ${ }^{23}$, o grande espaço de controvérsia entre elas.

É preciso relembrar que, nos moldes do modelo de Estado Liberal, "[...] o Poder Legislativo, que encarnava a vontade da Nação, tinha legitimidade para criar o Direito, mas não o Poder Judiciário, ao qual cabia tão somente aplicar aos casos concretos as normas anteriormente ditadas pelos parlamentos" 24 . Esse entendimento se justifica quando se analisa que somente na década de 90 diversos sistemas judiciais, como o brasileiro, passaram a adotar ou ampliar suas fórmulas de tutela judicial da Constituição ${ }^{25}$.

Porém, esta situação já não se aplica a uma sociedade tão complexa como a brasileira, a qual demanda constantemente uma postura mais ativa por parte do judiciário, a fim de que os seus direitos, constitucionalmente previstos,

23 SOUZA NETO, Claudio Pereira de Souza; SARMENTO, Daniel. Controle de Constitucionalidade e Democracia: algumas teorias e parâmetros de ativismo. In: SARMENTO, Daniel (coord.). Jurisdição Constitucional e Política. Rio de Janeiro: Forense, 2015, p. 73-114. p. 90.

24 SOUZA NETO, Claudio Pereira de Souza; SARMENTO, Daniel. Controle de Constitucionalidade e Democracia: algumas teorias e parâmetros de ativismo. p. 74-75.

25 SOUZA NETO, Claudio Pereira de Souza; SARMENTO, Daniel. Controle de Constitucionalidade e Democracia: algumas teorias e parâmetros de ativismo. p. 76. 
sejam efetivados, ou mesmo que aqueles grupos considerados em situação de vulnerabilidade não sejam "invisibilizados" pela vontade da maioria no sistema político. Neste viés, a aludida expansão da jurisdição constitucional, denominada de "judicialização da política", decorre de fatores como

[...] a maior consciência de direitos presente em nossa sociedade, o elevado grau de pluralismo político e social nela existente, o fortalecimento da independência do Poder Judiciário e a mudança na nossa cultura jurídica hegemônica - que passou a ver os princípios constitucionais como normas jurídicas vinculantes e a estimular o uso de instrumentos metodológicos mais flexíveis, como a ponderação e a argumentação calcada em valores - são fatores que contribuíram, cada um a seu modo, para que a jurisdição constitucional ganhasse um destaque na vida pública nacional até então inédito ${ }^{26}$.

Feitas estas considerações iniciais, passa-se para a análise em específico dos principais aspectos contidos no bojo de cada uma das teorias eleitas.

OS PROCEDIMENTALISTAS: O PRIMADO DA DEMOCRACIA

Como plano de fundo para o surgimento da "Teoria Discursiva habermasiana", identifica-se a transição paradigmática ocorrida entre os modelos de Estado Liberal e Social até chegar ao Estado Democrático de Direito, que enseja a discussão acerca da autonomia dos seus respectivos cidadãos, ponto central da construção teórica do autor alemão. Somada a esta questão, tem-se a própria legitimidade do Direito, como sistema normativo, questionada.

A lógica do Estado Liberal se mantém pelo equilíbrio de processos econômicos organizados conforme o mercado, quando isso não funciona, ou seja, quando há desigualdades econômicas e políticas exacerbadas em decorrência dessa situação, o Estado perde a sua eficácia na garantia da liberdade. Por mais que os espaços de opções em que os sujeitos agem livremente devem, sob a ótica do liberalismo, sofrer um mínimo de restrições ou proibições, surgiam - em contrapartida - situações, de desigualdade e, frente a elas, o aparato estatal não conseguia assegurar a liberdade.

26 SOUZA NETO, Claudio Pereira de Souza; SARMENTO, Daniel. Controle de Constitucionalidade e Democracia: algumas teorias e parâmetros de ativismo. p. 77-78. 
Era pressuposto da política deste modelo certo grau de igualdade, de modo que as pessoas pudessem concorrer no mesmo patamar - seja jurídico, social ou econômico. Esperava-se, portanto, o estabelecimento de conjunturas que possibilitassem a não discriminação no exercício das liberdades e, ademais, que houvesse certo equilíbrio no mercado econômico ${ }^{27}$, pois sem igualdade de fato, não há como pressupor uma consequente igualdade de Direito, o que - todavia - era difícil de ser conquistado.

Esse é justamente um dos problemas apontados, por Habermas, ao paradigma liberal: uma notável desigualdade de fato, na medida em que há, por exemplo, o crescimento de grupos econômicos capazes de controlar a própria cidadania, acarretando uma desigualdade de Direito. Diante da ineficácia do Estado na intervenção de questões de ordem privada, em virtude da perda da capacidade de se autorregular, acarreta-se, neste sentido, o não funcionamento do procedimento democrático e uma sociedade repleta de injustiças.

Em segundo lugar, aparece o Estado de Bem-Estado Social, o qual compreende dois aspectos importantes para o seu esboço:

[...] de um lado, surge a imagem de uma sociedade cada vez mais complexa, composta de esferas de ação funcionais, as quais forçam os atores individuais a assumir a posição marginal de "clientes", entregandoos às contingências de operações sistêmicas independentes; de outro lado, existe a expectativa de que essas contingências venham a ser controladas normativamente através das operações reguladoras de um Estado Social que intervém de modo preventivo ou reativo ${ }^{28}$.

Diante, então, da abstenção estatal frente às desigualdades provenientes da lógica do modelo de Estado Liberal, a política efetivada neste momento prevê uma postura mais interventiva dos agentes estatais numa tentativa de equilíbrio entre as esferas social, econômica e política. Em contrapartida, regulam-se as relações sociais e transforma-se a figura do Estado em fornecedor de direitos e a população, naquilo que o autor denomina de "clientes".

Ao analisar o modelo social de Estado, Habermas faz a crítica que, com esta

27 HABERMAS, Jürgen. Direito e democracia: entre facticidade e validade. 2. ed. v. II. Tradução de Flávio Beno Siebeneichler. Rio de Janeiro: Tempo Brasileiro, 1997. p. 139.

28 HABERMAS, Jürgen. Direito e democracia: entre facticidade e validade. p. 142. 
postura "providente", é possível que ocorra uma significativa perda de espaço para o exercício da autonomia, pois não haveria "[...] um aproveitamento em igualdade de chances, das liberdades negativas [...]"29 por parte dos cidadãos. Como exemplo deste argumento, Habermas cita os efeitos contrários produzidos pelas políticas de proteção à maternidade, as quais se direcionavam à proteção das mulheres no mercado de trabalho pois, segundo o autor,

[...] apenas agravara o risco do desemprego das mulheres, uma vez que normas de proteção do trabalho reforçaram a segregação do mercado de trabalho, situando-as no grupo de salários mais baixo, pois um direito de divórcio mais liberal sobrecarregou as mulheres com as consequências da separação e, finalmente, na medida em que o esquecimento das interdependências entre as regulações do direito social, da família e do trabalho fez com que as desvantagens específicas ao sexo se acumulassem ${ }^{30}$.

A mudança entre os dois primeiros paradigmas se deu por meio de uma transição de uma ótica individualista, em que havia - sobretudo - o privilégio de um Estado não interventor na esfera privada, para um arquétipo estatal cujo centro é o dirigismo e a redistribuição de bens e direitos.

Seguindo nesta linha, aparece o modelo do Estado Democrático de Direito, o qual deve assegurar a preservação da autonomia do cidadão (tanto privada, quanto pública). E isto ocorre por meio da constituição de uma razão comunicativa, o que pressupõe a permissão de que toda a população tenha acesso ao debate.

A legitimidade do Direito, por sua vez, é extraída da garantia concomitante das autonomias privada e pública - denominada "cidadã", bem como das manifestações das "formas comunicativas", sendo a ligação destes dois pressupostos a "chave da visão procedimental do direito" 31 . Sob a justificativa de que a forma pela qual a ordem jurídica estava posta nos modelos anteriores, porquanto "[...] a garantia da autonomia privada através do direito formal se revelou insuficiente e dado que a regulação social através do direito, ao invés de reconstituir a autonomia privada, se transformou numa ameaça para ela [...]"32, instituiu-se que a legitimidade dessa ordem jurídica é devida às formas de comunicação, que é a própria manifestação da autonomia.

29 HABERMAS, Jürgen. Direito e democracia: entre facticidade e validade. p. 145.

30 HABERMAS, Jürgen. Direito e democracia: entre facticidade e validade. p. 163.

31 HABERMAS, Jürgen. Direito e democracia: entre facticidade e validade. p. 145.

32 HABERMAS, Jürgen. Direito e democracia: entre facticidade e validade. p. 145. 
Sendo a legitimidade da ordem jurídica fundada no discurso, que é propriamente o diálogo travado com os próprios atingidos pela decisão, a proposta deste modelo de Estado é alcançar a efetiva autonomia, de maneira que os destinatários da ordem jurídica possam se enxergar como coautores do próprio Direito, cuja elaboração deve conter o diálogo proposto por esta teoria. Desta forma, a autonomia pública só pode ser percebida de maneira adequada, quando houver efetiva a participação e a autonomia privada - por outro lado - estiver garantida ${ }^{33}$. Para deixar clara a diferença entre autonomia pública e privada, é importante ressaltar que

[...] as autonomias privada e pública requerem uma à outra. Os dois conceitos são interdependentes; eles estão relacionados um ao outro por implicação material. Os cidadãos podem fazer um uso apropriado de sua autonomia pública, como algo garantido através de direitos políticos, só se eles forem suficientemente independentes em virtude de uma autonomia privada igualmente protegida em sua conduta de vida ${ }^{34}$.

É o equilíbrio entre a autonomia pública e privada que caracteriza o Estado Democrático de Direito, uma vez que os modelos anteriores de Estado, apesar de reconhecerem a autonomia das pessoas, lidam com elas de maneira separada e desequilibrada: a autonomia privada era assegurada pelo Estado Liberal; enquanto a pública pelo Estado Social ${ }^{35}$.

O Estado determina que esse impasse seja resolvido de modo que a autonomia tenha uma dupla forma: privada e pública. Por isso, Habermas entende que a legitimidade do direito surge de uma formação discursiva da opinião e da vontade de cidadãos que possuem os mesmos direitos - pressupondo um equilíbrio entre as igualdades de fato e de direito.

A proposta seria, então, uma alternativa aos modelos de Estado Liberal e Social, já que é um problema ter - de um lado - um Estado que não intervém na esfera privada e permite um domínio do mesmo propenso a gerar desequilíbrios na esfera social, em virtude do monopólio de grupos econômicos fortes. $E$, por

33 HABERMAS, Jürgen. Direito e democracia: entre facticidade e validade. p. 146.

34 HABERMAS, Jürgen. Direito e democracia: entre facticidade e validade. p. 137.

35 HABERMAS, Jürgen. A inclusão do outro: estudos de teoria política. Tradução de George Sperber e Paulo Astor Soethe. São Paulo: Loyola, 2002. p. 295. 
outro lado, também seria um óbice um Estado tipicamente paternalista, que resolvesse tudo pelas pessoas, cuja intervenção sob a justificativa da busca do "bem comum" pode acarretar, quando as situações são levadas ao extremo, uma sobreposição da autonomia pública pela privada, que é uma típica situação de tirania.

Habermas, na condição de procedimentalista, quer uma sociedade justa com igualdade de condições para a concorrência, de modo que se faça necessária a intervenção estatal. Porém, quando esta situação não se faz presente, há o surgimento de desigualdades e injustiças, o que é resolvido com a criação de um Estado interveniente. Isto ocorre no sentido de criar um contexto que seja possível a resolução dos problemas pelas próprias pessoas, muitas vezes, por meio de medidas não jurídicas, visto que a intenção da teoria discursiva é a criação de soluções secundárias.

Por isso, a racionalidade do discurso é um requisito essencial para compreensão da decisão final de Habermas. Racionalidade esta imaginada pela igualdade das pessoas, pois os defensores desta teoria entendem ser necessário que a consulta se dê a toda a população, com o fim de permitir que todos os lados sejam trazidos ao debate e, deste modo, a racionalidade resulte "[...] do tratamento igual das pessoas jurídicas protegidas em sua integridade" ${ }^{16}$.

A perspectiva habermasiana não considera a democracia como sendo um governo das maiorias, salientando o caráter deliberativo, pois

$\mathrm{Na}$ deliberação, os diversos participantes podem expor os seus pontos de vista e criticar os argumentos oferecidos pelos demais, com liberdade e igualdade. Para que um contexto propício para essa troca de argumentos e contra-argumentos possa se instaurar, as garantias do Estado de Direito são fundamentais. Sem liberdade e sem igualdade - que o Estado de Direito deve assegurar - não há diálogo verdadeiro, e a deliberação perde o seu potencial legitimador e racionalizador. ${ }^{37}$

O discurso é importante e, mais do que isso, a comunicação discursiva acaba sendo primordial, porque se não há um encontro entre os oponentes no debate e, com isso, a tentativa de se alcançar um consenso, acarreta-se um pré-julgamento

$36 \quad$ HABERMAS, Jürgen. Direito e democracia: entre facticidade e validade. p. 153.

37 SOUZA NETO, Claudio Pereira de Souza; SARMENTO, Daniel. Controle de Constitucionalidade e Democracia: algumas teorias e parâmetros de ativismo. p. 92-93. 
e a tutela, quando um lado acaba impondo a sua vontade ao outro. O defensor da teoria discursiva entende, desta maneira, que tem de ser estabelecido um diálogo entre as posições opostas, uma vez que "[...] na sua respectiva comunidade jurídica, ninguém é livre enquanto a sua liberdade implicar a opressão do outro. Pois a distribuição simétrica dos direitos resulta do reconhecimento de todos como membros livres e iguais" 38 .

O problema dos modelos anteriores consistia em tratar os direitos como bens e posses passíveis de distribuição, atitude que, na visão de Habermas ${ }^{39}$, está equivocada, porquanto os direitos se perfazem em relações construídas e conquistadas. Mais do que isso: para o autor, as políticas paternalistas do Estado Social tratam só do efeito do problema, na medida em que até conseguem resolver as desigualdades econômicas e políticas, mas tornam as pessoas dependentes, haja vista que o cerne do problema é a falta de autonomia. A questão é que tais práticas geram tamanha dependência da população para com o Estado, que ela é impedida de resolver seus próprios conflitos.

\section{A PROPOSTA PROCEDIMENTALISTA ALMEJA}

[...] cunhar o horizonte da pré-compreensão de todos os que participam, de algum modo e à sua maneira, da interpretação da constituição, toda transformação histórica do contexto social poderia ser entendida como um desafio para um reexame da compreensão paradigmática do direito. Esta compreensão, como aliás o próprio Estado de direito, conserva um núcleo dogmático, ou seja, a ideia da autonomia, segundo a qual os homens agem como sujeitos livres na medida em que obedecem às leis que eles mesmos estabeleceram, servindo-se de noções adquiridas num processo intersubjetivo ${ }^{40}$.

Conquanto se pretenda estabelecer condições para que todos sejam participantes ativos do debate, o problema central é que a forma como a sociedade se organiza exige a capacidade de seus membros de se considerarem autônomos. Caso este pressuposto não seja atendido, isto é, se as pessoas não se percebem como mais do que súditos, a teoria comunitarista não cumpre o seu

38 HABERMAS, Jürgen. Direito e democracia: entre facticidade e validade. p. 159.

39 HABERMAS, Jürgen. Direito e democracia: entre facticidade e validade. p. 159.

40 HABERMAS, Jürgen. Direito e democracia: entre facticidade e validade. p. 190. 
fim, sendo esse ponto algo de uma das maiores críticas substancialistas, como se verá a seguir.

Seria um erro, todavia, reduzir a teoria desenvolvida por Habermas a uma perspectiva meramente formalista, uma vez que a

[...] sua noção de procedimento não se desconecta em nenhum momento dos direitos fundamentais; depois, esses direitos são estendidos a todos como garantia de participação discursiva na construção substantiva desses próprios direitos, ou seja, da elaboração do código jurídico. Logo, os direitos fundamentais são simultaneamente condição e consequência desse procedimento discursivo ${ }^{41}$.

A teoria de Jürgen Habermas não se debruçou sobre a discussão relativa aos países de modernidade tardia, entretanto outros autores da teoria do discurso, como Álvaro Cruz, realizaram uma atualização da construção da teoria do discurso que permite compreender mais de perto as exigências para a autonomia em sociedades com maiores ou menores desigualdades seria diferente. Eles indicam que seria necessária a observância de direitos básicos divididos em cinco grandes grupos:

1 - Derivados da configuração politicamente autônomos do "direito à maior medida possível de iguais liberdades subjetivas de ação"; 2 "direitos ligados ao status de um membro numa associação voluntária de parceiros do direito"; 3 - "possibilidade de postulação judicial de direitos"; 4 - "direitos de participação nos processos de formação da opinião e da vontade"; 5 - "condições de vida garantidas social, técnica e ecologicamente"42.

O primeiro grupo prevê, basicamente, uma releitura discursiva dos direitos liberais clássicos ligados à liberdade, à vida, à integridade física, à propriedade, à intimidade, quanto aos direitos sociais como o direito do trabalho e à dignidade da pessoa humana. Já nos segundos, estaria incluída - por exemplo - a proibição de extradição, o direito de asilo, os direitos políticos e os direitos sociais e coletivos ${ }^{43}$. Ressalta-se que, sem as duas primeiras categorias de direitos fundamentais, não há direito legítimo. Dessa forma, afasta-se da postura procedimentalista a 41 CRUZ, Álvaro Ricardo de Souza. Habermas e o direito brasileiro. 2. ed. Rio de Janeiro: Lumen Juris, 2008. p. 178.

CRUZ, Álvaro Ricardo de Souza. Habermas e o direito brasileiro. p. 180-181. 
acusação de insensibilidade para problemas sociais apenas do paradigma jurídico calcado na autonomia.

A terceira categoria dos direitos fundamentais se sustenta na pretensão de uma justiça independente e imparcial nos seus julgamentos. São apenas garantias processuais, como a irretroatividade legislativa, a vedação do bis in idem penal e tributário. Em quarto lugar, estão os direitos de participação nos processos de formação da opinião e da vontade, os quais permitem uma modificação no conceito de democracia. E, por último, o autor abre espaço para os direitos difusos ligados, por exemplo, ao meio ambiente, ao biodireito, ao direito virtual ${ }^{44}$.

Atendidos esses pré-requisitos, pode-se dizer que a busca pela realização de um direito comunicativo preconiza a adoção da democracia como um procedimento diante de uma ação comunicativa e argumentativa para se chegar a decisões tidas como mais corretas perante a comunidade. Porém, é preciso que se observem tais decisões para que elas não usurpem, em última medida, os direitos supracitados previstos na Constituição ${ }^{45}$.

Extrai-se dos pressupostos elencados por Cruz que, mais importante do que o voto, são as condições essenciais para que ele se materialize. Logo, os direitos fundamentais são simultaneamente condição e consequência desse procedimento discursivo, visto que só há uma justificativa, dentro de uma versão procedimental da legitimidade democrática, para limitação à deliberação, que são estes direitos. Isto posto, ou seja, "respeitadas suas condições procedimentais, a soberania popular deve ter amplas possibilidades de decisão" ${ }^{46}$. O que se justifica pelo fato de que

[...] de um lado, os direitos fundamentais, como condição do procedimento discursivo, são pressupostos da comunicação e, portanto, despidos de conteúdo substantivo. Contudo, de outro lado, os direitos fundamentais, entendidos como consequências/produtos do procedimento discursivo, certamente estão repletos de substância ${ }^{47}$.

44 CRUZ, Álvaro Ricardo de Souza. Habermas e o direito brasileiro. p. 181.

45 CHUERI, Vera Karam de; GODOY, Miguel. Constitucionalismo e Democracia - Soberania e Poder Constituinte. p. 170-171.

46 SOUZA NETO, Claudio Pereira de Souza; SARMENTO, Daniel. Controle de Constitucionalidade e Democracia: algumas teorias e parâmetros de ativismo. p. 93.

47 CRUZ, Álvaro Ricardo de Souza. Habermas e o direito brasileiro. p. 183. 
Assim, a própria teoria do discurso reconhece a necessidade de o Judiciário intervir eventualmente, mas essa intervenção só se justifica "[...] se a deliberação majoritária violar esses direitos, justifica-se o controle de tais decisões do Poder Judiciário, que exerce o papel de guardião da democracia"48.

Esta perspectiva democrática como fundamento de legitimidade da ordem jurídica coloca-se, sem dúvida, contra possíveis arbítrios cometidos pela atividade jurisdicional, no sentido de que, dentro da razão comunicativa proposta por Habermas, "[...] não só os argumentos das partes, manifestados mediante pretensões de validade, são postos à refutação, mas também os argumentos do julgador. Todos envolvidos constituemse atores e participam da construção do discurso através do debate"49.

Habermas ${ }^{50}$ discute sobre a necessidade dos próprios cidadãos lutarem por espaços de discussão em busca do

[...] reconhecimento das interpretações reprimidas ou marginalizadas sobre suas carências, a fim de que novas situações factuais sejam reconhecidas como relevantes ou carentes de regulamentação e de que se negociem critérios sob os quais se possa trata com igualdade o que é igual e com desigualdade o que é desigual. Sem o princípio do tratamento em condições de igualdade, porém, transformado a fortiori em fundamento, não haveria base de sustentação para qualquer crítica ou reivindicação de revisão dos critérios antigos.

Esse aspecto é previsto pela teoria discursiva, sob a justificativa de que os critérios utilizados para a resolução de demandas anteriores não sofrerão modificações sem que haja a correspondente reivindicação, a qual ele entende ser tarefa dos próprios sujeitos envolvidos.

Ao Judiciário caberia apenas a verificação acerca da violação ou não dos direitos fundamentais já expostos, bem como o respeito ao princípio democrático. Ao passo que caberia ao Poder Legislativo a definição, a priori, dos meios e dos fins $^{51}$, que se perfaz na redução do espaço de atuação do primeiro poder prevista pelos procedimentalistas.

48 SOUZA NETO, Claudio Pereira de Souza; SARMENTO, Daniel. Controle de Constitucionalidade e Democracia: algumas teorias e parâmetros de ativismo. p. 94, grifo do autor.

49 COSTA, Renata Pereira Carvalho; COURA, Alexandre de Castro. A atuação do magistrado e sua conformação paradigmática: o desafio de materializar o Estado Democrático de Direito. p. 36.

50 HABERMAS, Jürgen. A inclusão do outro: estudos de teoria política. p. 335.

51 CRUZ, Álvaro Ricardo de Souza. Habermas e o direito brasileiro. p. 153-154. 
Seria incorreto afirmar que Habermas não aceita medidas intervencionistas do Estado, especialmente em sociedades que não passaram - ou vivenciaram de maneira distintas - o Estado de Bem-Estar Social, quando ele compreende que existem grupos sociais incapazes de integrar-se socialmente sem um auxílio estatal. Em contrapartida, o autor afirma que o modo como ocorre esta intervenção é que precisa ser repensado, para realmente consultar e dialogar com os grupos excluídos do seio social como procedimento de integrador da própria democracia, sob pena das políticas estatais se transformarem em mecanismos de opressão destas minorias.

Para que a situação de dependência não se perpetue, é essencial que o Judiciário não assuma uma postura de reparador dos erros cometidos pelos demais poderes ${ }^{52}$. É imprescindível que os destinatários destas ações tenham a plena consciência do caráter temporário nelas contido, caso contrário, restaria pactuada novamente uma relação de dependência ${ }^{53}$. Por isso, o cumprimento do propósito do agir comunicativo da teoria discursiva de Habermas é necessário, por criar condições para a operacionalização das estruturas discursivas, a de fundamentação e a de aplicação ${ }^{54}$.

Apesar de se colocar como contrário ao fato de o Judiciário assumir uma postura ativa, Habermas acredita que as demandas de caráter político devem ser enfrentadas quando postas sob jurisdição. Em contrapartida, as bases do controle de constitucionalidade - por exemplo - são mais restritas, com o objetivo de evitar a criação de uma "Jurisprudência de Valores", que importaria a condução da resolução das demandas judiciais pelos próprios valores aplicados às normas pelos magistrados.

Ressalva-se que Habermas não vislumbra uma interpretação restrita ao texto literal como aquela mais adequada, já que as atuais democracias exigem uma interpretação construtiva, tanto das normas, quanto dos princípios que compõem o sistema constitucional, além de "[...] uma leitura do sistema de direitos fundamentais não mais como garantia contra intervenções indevidas, mas como o fundamento que justifica pretensões positivas" 55 .

52 CRUZ, Álvaro Ricardo de Souza. Habermas e o direito brasileiro. p. 155.

53 CRUZ, Álvaro Ricardo de Souza. Habermas e o direito brasileiro. p. 186.

54 CRUZ, Álvaro Ricardo de Souza. Habermas e o direito brasileiro. p. 186.

55 CITTADINO, Gisele. Pluralismo, Direito e Justiça Distributiva: elementos da filosofia constitucional 


\title{
Álvaro $\mathrm{Cruz}^{56}$ considera essa limitação à usurpação de funções do Judiciário
} uma medida importante e, ao mesmo tempo,

\begin{abstract}
Tarefa árdua em um país cujo mundo da vida envolve tradições pouco democráticas, na qual a administração é assenhorada pelos titulares dos cargos públicos como algo particular e onde a magistratura, de uma forma geral, confunde a jurisdição com a figura mitológica de Zeus atirando seus raios de saber, de cultura e de uma ética divinizada sobre os mortais.
\end{abstract}

Uma cidadania ativa, como almeja os procedimentalistas, requer que sejam instituídos mecanismos propiciadores de participação da comunidade na interpretação do texto constitucional. E tanto as decisões políticas, quanto as judiciais, não sejam tomadas exclusivamente pelos governantes, mas que haja compatibilização entre o direito legítimo e a democracia, com a finalidade de impedir que o juiz assuma funções tipicamente legislativas e garantir que o povo participe efetivamente da elaboração das leis que os regem.

\subsection{Os substancialistas e a pretensão de primazia dos direitos fundamentais}

Enquanto os procedimentalistas estabelecem uma relação de coesão entre democracia e legitimidade do Direito com o objetivo de atingir uma efetiva autonomia dos cidadãos, por intermédio da ampla participação, tanto nas decisões tomadas no âmbito legislativo de criação das normas legais, quanto na seara judicial pela interpretação constitucional, as preocupações dos substancialistas giram em torno da concretização do texto constitucional pela atuação judicial. A dicotomia que pode ser estabelecida entre os modelos em análise estabelece-se, segundo Souza Neto e Sarmento ${ }^{57}$, basicamente em dois campos: a função da Constituição na sociedade e o espaço mais adequado para a jurisdição constitucional.

Discute-se, em primeiro lugar, como as duas teorias tratam a questão da elaboração das constituições no que tange ao seu conteúdo. O procedimentalismo sustenta que a Constituição tem um papel essencial na previsão das normas políticas, com vistas à garantia do cunho democráti$\mathrm{co}^{58}$. Em posição contrária, o substancialismo defende que o fato das constituições preverem um conteúdo substantivo é legítimo, mesmo que se refira a direitos que não estejam relacionados ao princípio democrático ${ }^{59}$. Por isso, no exercício hermenêutico, os substancialistas não restringem a procura por soluções no espaço da Constituição, mesmo que isto implique uma interpretação mais extensiva ${ }^{60}$.

\section{Com relação ao espaço mais adequado para a realização da jurisdição} constitucional, a diferenciação dos pressupostos de cada teoria ocorre de maneira

contemporânea. 2. ed. Rio de Janeiro: Lumen Juris, 2000. p. 212.

56 CRUZ, Álvaro Ricardo de Souza. Habermas e o direito brasileiro. p. 208.

57 SOUZA NETO, Claudio Pereira de Souza; SARMENTO, Daniel. Controle de Constitucionalidade e Democracia: algumas teorias e parâmetros de ativismo. p. 89.

58 SOUZA NETO, Claudio Pereira de Souza; SARMENTO, Daniel. Controle de Constitucionalidade e Democracia: algumas teorias e parâmetros de ativismo. p. 89-90.

59 SOUZA NETO, Claudio Pereira de Souza; SARMENTO, Daniel. Controle de Constitucionalidade e Democracia: algumas teorias e parâmetros de ativismo. p. 90.

60 SOUZA NETO, Claudio Pereira de Souza; SARMENTO, Daniel. Controle de Constitucionalidade e Democracia: algumas teorias e parâmetros de ativismo. p. 90. 
Novos Estudos Jurídicos

mais acentuada, já que o procedimentalismo prevê que somente para assegurar a ordem democrática é que seria possível uma atitude que eles consideram mais "agressiva", nos demais casos a postura correta é de "autocontenção". Ao passo que o substancialismo, não faz distinção entre as situações que requerem ou não uma atuação mais ativa por parte da jurisdição constitucional61.

Colocando como plano de fundo o tensionamento que existe entre legislação e jurisdição, visto que "[...] a primeira é fruto da vontade geral (majoritária) e a segunda coloca freios nessa mesma vontade geral, sendo, portanto, contramajoritária"62, é possível traçar o ponto crucial das teorias analisadas. Isso, pois o enfoque dado pelos substancialistas é a jurisdição, o que é encarado como um enfraquecimento da democracia pelos procedimentalistas, sob o argumento de que restaria ausente a legitimidade da justiça constitucional ${ }^{63}$. Evidenciase, desta maneira, que a corrente substancialista não considera o exercício do protagonismo judicial como algo ruim, exceto nos casos em que este não é direcionado à garantia dos direitos da população, cujo dever, entendem, pertence ao Judiciário.

Isto não implica dizer que é permitido aos magistrados pautarem suas decisões em convicções tipicamente pessoais distante de qualquer amparo normativo para justificarem a defesa de direitos fundamentais. O problema é ocasionado pela distorção do que seria uma postura ativa do Judiciário, ou seja, quando há a construção de uma decisão que extrapola as balizas do ordenamento jurídico ${ }^{64}$. Apesar deste não dar conta de tutelar todas as transformações das relações sociais, tendo em vista a incompatibilidade entre o tempo do Direito e o da sociedade, o ordenamento jurídico, em especial a Constituição Federal, é o parâmetro fundamental para a atuação jurisdicional, o que evita julgamentos conforme a consciência do magistrado.

$\mathrm{Na}$ visão substancialista, portanto, o ativismo judicial realizado às avessas,

61 SOUZA NETO, Claudio Pereira de Souza; SARMENTO, Daniel. Controle de Constitucionalidade e Democracia: algumas teorias e parâmetros de ativismo. p. 90.

62 STRECK, Lenio Luiz. Verdade e Consenso. Constituição, Hermenêutica e Teorias Discursivas. Da possiblidade à necessidade de respostas corretas em direito. 5. ed. São Paulo: Saraiva, 2014. p. 22.

63 STRECK, Lenio Luiz. Verdade e Consenso. Constituição, Hermenêutica e Teorias Discursivas. Da possiblidade à necessidade de respostas corretas em direito. p. 24.

64 TASSINARI, Clarissa. Ativismo judicial: uma análise da atuação do Judiciário nas experiências brasileira e norteamericana. p. 38. 
ou seja, decisões judiciais pautadas no mero julgamento pessoal e para além do que seria uma saída da inércia judicial, não deve prosperar, pois se vale da discricionariedade e cria decisionismos ${ }^{65}$. Uma vez provocado, o Judiciário deve atuar de maneira ativa em prol da resolução dos conflitos; do controle de políticas públicas, enfim da própria concretização dos direitos fundamentais positivados constitucionalmente sem extrapolar os limites semânticos do texto constitucional.

Para Streck ${ }^{66}$, o fenômeno da judicialização da política e o ativismo às avessas se distinguem da seguinte forma:

[...] um juiz ou tribunal pratica ativismo quando decide a partir de argumentos de política, de moral, enfim, quando o direito é substituído pelas convicções pessoais de cada magistrado (ou de um conjunto de magistrados); já a judicialização é um fenômeno que exsurge a partir da relação entre os poderes do Estado (pensemos, aqui, no deslocamento do polo de tensão dos Poderes Executivo e Legislativo em direção da justiça constitucional) [...].

A judicialização da política é um fenômeno recorrente na prática jurisdicional em virtude da ineficácia da atuação dos poderes Executivo e Legislativo, que ocasiona o ingresso de demandas políticas na seara judicial, sendo que o Judiciário não deve se imiscuir de conferir tratamento a elas. O grande impasse, de acordo com o viés substancialista, não é propriamente a materialização do texto constitucional pelo Judiciário, mas somente se isto ocorrer ao livre arbítrio do juiz ${ }^{67}$ - o que acarretaria, em contrapartida, o decisionismo.

A crítica ao "ativismo à brasileira"68 é consensual entre os substancialistas e

65 Sobre a linha tênue entre o ativismo e o decisionismo, Streck (Jurisdição Constitucional e Decisão Jurídica. São Paulo: Revista dos Tribunais, 2013. p. 294-295) dá o seguinte exemplo: “[...] a livre apreciação da prova ou o livre convencimento do juiz - e as inúmeras decisões que tratam disso (por exemplo, o recente processo do Mensalão, que muito se utilizou do 'livre convencimento') - seriam enquadrados em que conceito? Quando o STF diz que, com base no princípio da verdade real, aplica a livre apreciação da prova, ele está praticando o quê? A democracia? Ou ele está usurpando a competência do Legislativo e do próprio Estado Democrático de Direito?".

66 STRECK, Lenio Luiz. Verdade e Consenso. Constituição, Hermenêutica e Teorias Discursivas. Da possiblidade à necessidade de respostas corretas em direito. p. 589.

67 "Por exemplo, quando o STF decide que, no art. 366 do CPP, a prova considerada urgente fica ao arbítrio do juiz decidir, está não somente fazendo ativismo, com a institucionalização da discricionariedade judicial - ponto importante para aferir o grau de ativismo e da judicialização -, como também está 'legislando'. Não parece que o legislador, ao estabelecer, nos marcos da democracia, que a prova considerada urgente possa ser colhida de forma antecipada, tenha 'querido' deixar isso ao bel-prazer do juiz... Bom, mas foi isso que o STF disse que o dispositivo 'quis dizer'” (STRECK, Lenio Luiz. Jurisdição Constitucional e Decisão Jurídica. p. 294).

68 Tassinari explica que a utilização da "[...] expressão ativismo judicial à brasileira evidencia duas importantes questões: primeiramente, a caracterização do ativismo judicial como experiência que não é própria (originária) do contexto brasileiro (neste sentido, à brasileira sinalizaria simplesmente para a conjugação de duas tradições). Por outro lado, pode também estar implícita uma crítica à utilização destes termos de modo despojado do contexto 
procedimentalistas, uma vez que ambos reconhecem se tratar de uma postura um tanto quanto perigosa, já que se pauta do ato de vontade do magistrado ${ }^{69}$. Mas enquanto os procedimentalistas defendem a redução da atuação judicial frente à atuação autônoma da cidade, os substancialistas entendem que tal atitude não cumpriria o fim idealidade, pois

[...] a desjuridificação, bem como a desconstituicionalização, favorecem a manutenção dos privilégios e desigualdades. A desjuridificação, no Brasil, não amplia espaços da cidadania, uma vez que, enquanto a Constituição não é concretizada, não há nem um espaço da cidadania ${ }^{70}$.

Ao partir do pressuposto de que a interpretação constitucional se perfaz numa disputa entre paradigmas, o Estado Democrático de Direito é calcado na contramão dos modelos de Estado Liberal e Social como num direito transformador da realidade. Ou seja, "[...] não é mais ordenador, como na fase liberal; tampouco é (apenas) promovedor, como era na fase do welfare state (que nem ocorreu no Brasil)" ${ }^{\prime 11}$. As "[...] posturas substancialistas [...] acoplam à noção de Estado o conteúdo material das Constituições que apontam para a mudança do status quo da sociedade, colocando grande ênfase no papel da justiça constitucional na efetivação dos direitos fundamentais-sociais"72 .

Sendo o direito contido neste novo paradigma estatal de cunho transformador, o tratamento - tanto da judicialização da política, quanto do consequente ativismo judicial - constitui um ponto de divergência entre as teorias. Assim, caberia à própria população discutir sobre tais questões e chegar a um "consenso" sobre a decisão a ser tomada. Para a corrente substancialista, crer nesta situação é uma ilusão, quando se está diante de países que sequer conseguem efetivar os direitos mais básicos à sua população, como é o caso do Brasil. Seria difícil exigir, em países de modernidade tardia, tamanha autonomia dos cidadãos para de seu surgimento, o que implica, a um tempo, a transposição equivocada de um conceito e, a outro, a ausência de uma necessária adaptação do que se apreende do constitucionalismo norte-americano [...]". (TASSINARI, Clarissa. Ativismo judicial: uma análise da atuação do Judiciário nas experiências brasileira e norte-americana. p. 92).

69 TASSINARI, Clarissa. Ativismo judicial: uma análise da atuação do Judiciário nas experiências brasileira e norteamericana. p. 93.

70 STRECK, Lenio Luiz. Verdade e Consenso. Constituição, Hermenêutica e Teorias Discursivas. Da possiblidade à necessidade de respostas corretas em direito. p. 100.

71 STRECK, Lenio Luiz. Verdade e Consenso. Constituição, Hermenêutica e Teorias Discursivas. Da possiblidade à necessidade de respostas corretas em direito. p. 10-11.

72 STRECK, Lenio Luiz. Verdade e Consenso. Constituição, Hermenêutica e Teorias Discursivas. Da possiblidade à necessidade de respostas corretas em direito. p. 101. 
participarem de um diálogo entre grupos com condições tão díspares, ou seja, que não alcançaram consciência necessária para lutar por seus direitos.

Torna-se difícil acreditar que os grupos vulneráveis destes países estariam em pé de igualdade para tal embate e, mais do que isso, que a decisão obtida neste momento não seria fruto da prevalência de interesses de uma "maioria eventual". Sustentar, como os procedimentalistas brasileiros, que o problema de se estabelecer um diálogo racional nestes países é que a exigência pela autonomia seria simplesmente maior parece ser insuficiente para se adequar a este tipo de população.

Os autores substancialistas enxergam que os países de modernidade tardia precisam de uma Teoria da Constituição Adequada às suas especificidades, bem como uma atuação intervencionista da jurisdição constitucional sem disseminar uma prática ativista às avessas como tem sido recorrente, a qual contribui somente para a ineficácia dos direitos fundamentais ${ }^{73}$. Nessa perspectiva, a proposta procedimental de relegar ao Judiciário a tarefa de assegurar a prática democrática de formação da vontade e da opinião política, por meio da cidadania, não é suficiente, tendo em vista o desejo de construção dos pilares do Estado Social no contexto brasileiro ${ }^{74}$. Streck ${ }^{75}$ alerta que

[...] as inadequações das leis só podem ser resolvidas pela tarefa construtiva dos juízes, e os indivíduos encarregados de conduzir os processos democráticos necessitam de um espírito crítico para compreender a complexidade da própria democracia, sob pena de, a partir de uma formação dogmática e autoritária, construir a antítese do processo democrático. Afinal, se o Estado de Direito [...] é algo diferente do Estado de lei [...], só pode sê-lo na medida em que for para além da simples conformidade "processual" assim que a questão da justiça for colocada e assim que afete até as regras jurídicas já constituídas.

Com base nestas considerações sobre a realidade da jurisdição constitucional de países de modernidade tardia, faz-se necessária a manutenção do caráter dirigente e compromissário da Constituição. Isso porque se pretende tão somente vincular o "[...] legislador aos ditames da materialidade da Constituição, pela

73 STRECK, Lenio Luiz. Verdade e Consenso. Constituição, Hermenêutica e Teorias Discursivas. Da possiblidade à necessidade de respostas corretas em direito. p. 15-16.

74 STRECK, Lenio Luiz. Verdade e Consenso. Constituição, Hermenêutica e Teorias Discursivas. Da possiblidade à necessidade de respostas corretas em direito. p. 26.

75 STRECK, Lenio Luiz. Jurisdição Constitucional e Decisão Jurídica. p. 155. 
exata razão de que, nesse contexto, o Direito continua a ser um instrumento de implementação de políticas públicas"76.

Por isso, as noções de constituição dirigente não deixaram de ser importante especialmente quando as promessas da modernidade "igualdade, justiça social e garantia dos direitos fundamentais contidas na Constituição Federal de 1988 ainda padecem de concretização"77. Surge, como uma alternativa para o resgate destas promessas, o Judiciário, "[...] onde o acesso à justiça assume um papel de fundamental importância, através do deslocamento da esfera de tensão, até então calcada nos procedimentos políticos, para os procedimentos judiciais"78.

É preciso deixar claro que os substancialistas não pretendem reduzir, tampouco substituir os preceitos da corrente procedimentalista, eles apenas consideram que, antes da primazia pelo pacto democrático e, por conseguinte, da observância dos procedimentos que ela implica - e aqui sem qualquer reducionismo desta teoria -, deve ocorrer o processo hermenêutico. Pautado nesta distinção, Streck ${ }^{79}$ explica que:

A hermenêutica não proíbe que se faça essa justificação/explicitação de forma procedural. Só que a hermenêutica não concorda com a eliminação do primeiro passo na compreensão, que é exatamente o elemento hermenêutico. Em outras palavras, não sou contra a teoria procedimental; só afirmo que o modo de ser manifestativo da compreensão precede a teoria do conhecimento.

Pode-se dizer que os procedimentos democráticos previstos pelos procedimentalistas são considerados, sobremaneira, importantes para o substancialismo. Contudo, a corrente considera que a sua realização é somente uma parte do regime democrático, para o qual se faz imprescindível que a própria gênese seja efetivamente democrática, o que ultrapassa a esfera dos procedimentos.

76 STRECK, Lenio Luiz. Jurisdição Constitucional e Hermenêutica: Perspectivas e Possibilidades de Concretização dos Direitos Fundamentais-Sociais no Brasil. Novos Estudos Jurídicos. v. 8, n. 2, p. 257-301, maio/ago. 2003. p. 277.

77 STRECK, Lenio Luiz. Jurisdição Constitucional e Hermenêutica: Perspectivas e Possibilidades de Concretização dos Direitos Fundamentais-Sociais no Brasil. p. 259.

78 STRECK, Lenio Luiz. Jurisdição Constitucional e Decisão Jurídica. p. 151.

79 STRECK, Lenio Luiz. Verdade e Consenso. Constituição, Hermenêutica e Teorias Discursivas. Da possiblidade à necessidade de respostas corretas em direito. p. 15. 
Denota-se que a defesa tanto da democracia, quanto dos direitos fundamentais, bem como do núcleo político da Constituição, é comum às teorias procedimentalista e substancialista, além de não admitirem a sua respectiva utilização para justificar a negação de direitos fundamentais, nem o incentivo à proliferação de decisionismos e de arbitrariedades ${ }^{80}$. Entretanto, o ponto que de distinção entre elas seria o caminho escolhido para se alcançar a coexistência do princípio democrático e do constitucionalismo, já que uma acredita que seja essencialmente a participação democrática nas decisões e a outra defende a atuação interventiva do Judiciário.

\section{AS DECISÕES NA ADI N. 4277 E ADPF N. 132 DO SUPREMO TRIBUNAL FEDERAL NAS PERSPECTIVAS PROCEDIMENTALISTA E SUBSTANCIALISTA}

Neste terceiro momento, as ponderações feitas sobre as principais teorias da jurisdição constitucional constituirão a base para a análise das decisões obtidas na Arguição de Descumprimento de Preceito Fundamental n. 132 e na Ação Direta de Inconstitucionalidade n. 4277 interpostas no Supremo Tribunal Federal pelo Procurador-Geral da República e pelo Governador do Estado do Rio de Janeiro, respectivamente. Mediante a identidade dos pedidos, ambas as ações pleiteavam junto ao STF a interpretação do artigo 1.723 do Código Civil conforme à Constituição Federal de 1988, a fim de permitir a aplicação do referido dispositivo legal às uniões entre pessoas do mesmo sexo ${ }^{81}$.

$\mathrm{Na}$ oportunidade, os pedidos formulados pelas ações foram julgados procedentes, apesar dos ministros utilizarem fundamentos divergentes, o que Ihes conferiu a similitude dos efeitos práticos. Ou seja, passou-se a reconhecer a união homoafetiva como válida perante o ordenamento jurídico, apesar da redação do Código Civil. O preceito legal na visão do tribunal deve ser interpretado

80 STRECK, Lenio Luiz. Verdade e Consenso. Constituição, Hermenêutica e Teorias Discursivas. Da possiblidade à necessidade de respostas corretas em direito. p. 16.

81 "AADI 4277 foi protocolada na Corte inicialmente como ADPF 178. A ação buscou a declaração de reconhecimento da união entre pessoas do mesmo sexo como entidade familiar. Pediu, também, que os mesmos direitos e deveres dos companheiros nas uniões estáveis fossem estendidos aos companheiros nas uniões entre pessoas do mesmo sexo. Já na Arguição de Descumprimento de Preceito Fundamental (ADPF) 132, o governo do Estado do Rio de Janeiro (RJ) alegou que o não reconhecimento da união homoafetiva contraria preceitos fundamentais como igualdade, liberdade (da qual decorre a autonomia da vontade) e o princípio da dignidade da pessoa humana, todos da Constituição Federal. Com esse argumento, pediu que o STF aplicasse o regime jurídico das uniões estáveis, previsto no artigo 1.723 do Código Civil, às uniões homoafetivas de funcionários públicos civis do Rio de Janeiro" (STF. Supremo Tribunal Federal. Supremo reconhece união homoafetiva. Disponível em: <http://www. stf.jus.br/portal/cms/verNoticiaDetalhe.asp?idConteudo=178931>. Acesso em: 10 jul. 2017.). 
conforme a Constituição, sob a alegação de que o texto constitucional não faz distinção em relação ao sexo das pessoas, ao passo que o referido artigo do Código Civil estabelece como requisito para o reconhecimento da união estável a diversidade de sexos.

Não reconhecer as uniões entre pessoas do mesmo sexo seria, de acordo com os argumentos utilizados pelos requerentes, típico caso de discriminação inclusive com tutela legal. Estariam, portanto, feridos diversos direitos fundamentais assegurados constitucionalmente como a igualdade, a diversidade, a não discriminação, dentre outros.

Sob a ótica substancialista, permitir uma interpretação conforme a Constituição Federal seria extrapolar as funções jurisdicionais, uma vez que o preceito legal do Código Civil possui uma redação restrita no sentido de considerar apenas as uniões entre homem e mulher como válidas da mesma forma que o texto constitucional, visto que o parágrafo $3^{\circ}$ do artigo 226, o qual trata especificamente desta matéria, também não dá margens - segundo os críticos - para outra interpretação que não seja a de que o instituto da união estável somente pode ser estabelecido com o preenchimento do requisito da diversidade sexual.

A crítica gira em torno da alegação do emprego errôneo do instrumento da interpretação conforme a Constituição, já que há similitude nas redações sob análise. Diferente do que foi realizado nestas decisões, os substancialistas admitem que a função jurisdicional, exercida pelo STF, deveria se valer da interpretação conforme somente nos casos em que houvesse abertura em virtude de omissões ou problemáticas acerca da (in)constitucionalidade, ou mesmo da (in)compatibilidade entre as normas infraconstitucionais e a Constituição Federal. Esta situação representaria um impeditivo à procedência dos aludidos pedidos, haja vista o limite prático contido no próprio artigo 226.

A indeterminação do direito é a principal justificativa que permite uma atuação, por parte do magistrado, para além da subsunção do fato à norma, haja vista o descompasso que muitas vezes é estabelecido entre as peculiaridades do caso prático e o conjunto normativo. No entanto, os críticos da decisão alegam 
que este fator não está presente no dispositivo legal em questão, uma vez que ele é taxativo ao considerar como válidas apenas as relações entre casais de sexo distinto.

Sobre esta visão crítica, um dos argumentos adotado pelo relator trata justamente de não se interpretar de maneira reducionista o próprio conceito de família, sob pena do texto constitucional ser empregado num discurso preconceituoso ${ }^{82}$. Mediante o fundamento de impossibilidade do não reconhecimento de outras modalidades de família, por exemplo, a "monoparental", a qual prescinde do requisito "homem e mulher" para a atribuição deste status, o ministro vota pelo reconhecimento da união entre pessoas do mesmo sexo ${ }^{83}$.

Ainda de acordo com o entendimento do relator, "[...] a nossa Magna Carta não emprestou ao substantivo 'família' nenhum significado ortodoxo ou da própria técnica jurídica. Recolheu-o com o sentido coloquial praticamente aberto que sempre portou como realidade do mundo do ser"84. Isso leva a afirmar que não há espaço para a diferenciação entre a constituição fática ou formal do conceito de família, tampouco para a distinção - de forma que implique a supressão de direitos - entre as relações homossexuais e as heterossexuais.

Ocorre que, no julgamento em questão, houve intensa participação dos cidadãos interessados na causa, bem como de instituições representativas da sociedade civil, por intermédio da figura do "amicus curiae", cujas manifestações foram cruciais no auxílio à formulação dos argumentos utilizados nos votos dos ministros no julgamento em questão ${ }^{85}$, conforme destaque do ministro Celso de Mello em seu voto. Naquela ocasião, foram oportunizadas manifestações de pessoas com maior conhecimento das especificidades da causa, o que agrada os adeptos ao procedimentalismo, em virtude do respeito ao princípio democrático, uma vez que "[...] embora o juiz dirija o processo de forma ativa, passa a fazê-lo sob uma perspectiva comparticipativa, policêntrica e interdependente entre os atores sociais que participam da formação das decisões"86. Ao elevar a condição

82 BRASIL. Supremo Tribunal Federal. Ação Direta de Inconstitucionalidade 4.274/DF. Relator: Min. Ayres Britto. Pleno. Brasília, 23.11.2011c. Disponível em: <http://redir.stf.jus.br/paginadorpub/paginador. jsp?docTP=TP\&docID=1955301>. Acesso em: 30 jun. 2017. p. 656.

83 BRASIL. Supremo Tribunal Federal. Ação Direta de Inconstitucionalidade 4.274/DF. p. 656.

84 BRASIL. Supremo Tribunal Federal. Ação Direta de Inconstitucionalidade 4.274/DF. p. 648.

85 BRASIL. Supremo Tribunal Federal. Ação Direta de Inconstitucionalidade 4.274/DF. p. 823.

86 ESPINDOLA, Angela Araújo da Silveira; SANTOS, Igor Raatz dos. O processo civil no Estado democrático de direito e a releitura das garantias constitucionais: entre a passividade e o protagonismo judicial. Novos Estudos 
do cidadão de "[...] mero recipiente da intervenção social do Estado" ${ }^{17}$ a um efetivo participante, o processo adquire, então, um cunho democrático.

Os ministros ressalvam, em diversos momentos da deliberação, que a decisão do órgão foi tomada em caráter provisório, tendo em vista a necessidade dessa situação fática ser discutida pelo Poder Legislativo. Ocorre que, diante das demandas apresentadas, o Judiciário não poderia se abster de tal julgamento, tampouco esperar que tal matéria fosse regulamentada pelo legislador, como pode se extrair do voto de Gilmar Mendes:

Evidentemente essa proteção poderia ser feita - ou talvez devesse ser feita - primariamente pelo próprio Congresso Nacional, mas também se destacou da tribuna as dificuldades que ocorrem nesse processo decisório, em razão das múltiplas controvérsias que se lavram na sociedade em relação a esse tema. E aí a dificuldade do modelo representativo, muitas vezes, de atuar, de operar ${ }^{88}$.

No trecho destacado, restou claro que o magistrado não desconhece que a tomada de atitude deveria partir do Poder Legislativo, porém ele destaca os entraves que, porventura, acometem os que foram efetivamente eleitos para a representação dos interesses do povo. Trata-se de uma disputa de interesses de grupos antagônicos, que impedem o reconhecimento dos direitos daqueles que eventualmente são classificados como minorias.

Em momento algum, os ministros negam uma atuação positiva nas decisões em comento, pelo contrário, os votos proferidos na sessão de julgamento refletiam exatamente esta preocupação dos julgadores com uma possível alegação de usurpação de função do Legislativo pelo Judiciário. Contudo, um dos argumentos utilizados, por exemplo, pelo ministro Gilmar Mendes ${ }^{89}$ para afastar este tipo de acusação sustenta-se na defesa dos direitos fundamentais.

É o que corrobora o seguinte trecho do voto proferido pelo ministro Luiz Fux, o qual põe em evidência o papel da atividade jurisdicional, sobretudo, como defensora da concretização dos direitos fundamentais:

Jurídicos, v. 16, n. 2, p. 150-169, 2011. p. 160.

87 ESPINDOLA, Angela Araújo da Silveira; SANTOS, Igor Raatz dos. O processo civil no Estado democrático de direito e a releitura das garantias constitucionais: entre a passividade e o protagonismo judicial. p. 159.

88 BRASIL. Supremo Tribunal Federal. Ação Direta de Inconstitucionalidade 4.274/DF. p. 730.

89 BRASIL. Supremo Tribunal Federal. Ação Direta de Inconstitucionalidade 4.274/DF. p. 766. 
O processo jurisdicional é, por excelência, o locus da proteção dos direitos fundamentais. A jurisdição, como função primordial do Estado, precisa estar dirigida à consagração dos direitos fundamentais, como, de resto, a atividade estatal como um todo - do contrário, perde-se a própria razão de ser do Estado. Quando o processo resulta em flagrante e disseminada violação dos direitos fundamentais - sobretudo aqueles que dizem com os direitos da personalidade, como os de que ora se cuida -, o Estado tem o dever de operar os instrumentos de fiscalização de constitucionalidade aptos a derrotar o abuso ${ }^{90}$.

Isso porque se empregava o artigo 1.723 do Código Civil como óbice à concretização de direito fundamental, pois ele servia de justificativa para o não reconhecimento das uniões homoafetivas. Por meio, então, de uma interpretação literal restritiva, consideravam-se - para efeitos legais do instituto da união estável - apenas as relações estabelecidas entre homem e mulher.

Além desse argumento, o relator Ayres Britto é enfático ao afirmar que, ao julgar pela procedência das ações, não houve criação do Direito, pois o ministro - e aqueles que o seguiram - não reconheceram a existência de uma lacuna na legislação, mas tão somente propiciaram uma interpretação que superou o texto literal da norma. Apontou, ainda, "[...] que a própria Constituição contém elementos interpretativos que habilitam esse julgamento do Supremo a concluir pela paridade de situações jurídicas, sem lacuna e, portanto, sem a necessidade de preenchimento ou colmatação"91.

Em abandono, portanto, à figura do juiz "boca da lei", que reproduz mecanicamente a literalidade do texto normativo nas suas decisões, o Judiciário assume - no paradigma do Estado Democrático de Direito - uma função que permite, em certa medida e à luz dos preceitos constitucionais, o exercício da criatividade na aplicação do Direito às situações fáticas jurisdicionadas. O que não significa que ao magistrado são permitidos julgamentos impulsionados por discricionariedades e meras convicções pessoais, ao contrário, ele é movido por uma hermenêutica condizente com a complexidade adquirida pelas demandas judiciais, que evidentemente o Direito não deu conta de acompanhar a evolução.

Postos, por Streck ${ }^{92}$, como faces da mesma moeda, a judicialização e o ativismo

90 BRASIL. Supremo Tribunal Federal. Ação Direta de Inconstitucionalidade 4.274/DF. p. 664.

91 BRASIL. Supremo Tribunal Federal. Ação Direta de Inconstitucionalidade 4.274/DF. p. 746.

92 STRECK, Lenio Luiz. Jurisdição Constitucional e Decisão Jurídica. p. 290. 
Novos Estudos Jurídicos

nos permitem supor que o aumento das demandas de cunho político no judiciário brasileiro esteja vinculado à incapacidade de o Legislativo conferir a tutela às relações sociais na mesma velocidade em que as relações sociais se desenvolvem. $E$, de acordo com a própria tese substancialista, a justiça constitucional não pode retroceder àquela postura absenteísta, típica do modelo de Estado Liberal, devendo assumir uma atitude com caráter mais intervencionista ${ }^{93}$.

Tomando por base este fundamento, o intervencionismo de que falam os substancialistas contempla o "[...] cumprimento dos preceitos e princípios ínsitos aos Direitos Fundamentais Sociais e ao núcleo político do Estado Social previsto na Constituição de 1988"94. Causa certa estranheza, então, que estes mesmos autores critiquem a decisão tomada pelos ministros do Supremo Tribunal Federal no caso envolvendo a equiparação das uniões homoafetivas às uniões estáveis, já que esta teve como impulso a própria defesa dos direitos aos quais são atribuídos o status de fundamentais.

Diante do julgamento atribuído a este caso concreto e dos preceitos elucidados sobre as teses substancialistas e procedimentalistas, observa-se a existência de uma linha muito tênue que separa estas duas posições: ambas defendem os pressupostos do funcionamento da ordem democrática, bem como proporcionam a concretização dos direitos fundamentais. Assim, quando se vislumbra a autonomia como uma forma de garantir a igualdade e combater a percepção desigual, a separação na linha traçada pela teoria do discurso e pela crítica hermenêutica hoje, no Brasil, é nebulosa.

Em última análise, as correntes são favoráveis ao que se pode denominar de "prática ativista legítima", desde que - por um lado - faça valer o princípio democrático por meio do diálogo entre os lados opostos de interesse na causa e - de outro - a interpretação decorrente da aplicação do direito ao caso, desde que não extrapole em demasia os limites semânticos do texto normativo.

93 STRECK, Lenio Luiz. Jurisdição Constitucional e Hermenêutica: Perspectivas e Possibilidades de Concretização dos Direitos Fundamentais-Sociais no Brasil. p. 281.

94 STRECK, Lenio Luiz. Jurisdição Constitucional e Hermenêutica: Perspectivas e Possibilidades de Concretização dos Direitos Fundamentais-Sociais no Brasil. p. 281. 
No Estado Liberal, os holofotes estavam sobre a atuação do Poder Legislativo, tendo em vista a primazia da lei. Já no Estado Social, o Executivo exercia o protagonismo para, no Estado Democrático de Direito, o Judiciário assumir tal posição. $\mathrm{O}$ que se torna evidente pelo fato de que a própria sociedade demanda uma postura mais ativa do Judiciário, tendo em vista as inúmeras violações a direitos, inclusive, os de caráter fundamental.

Existe, porém, a dificuldade em compatibilizar as diretrizes estabelecidas pelas principais correntes doutrinárias que versam sobre a jurisdição constitucional. Pois, como detalhado, é notável certo embate entre as teses procedimentalista e substancialista, em que o procedimentalismo entende que a atividade judicante deve se resumir à proteção da criação democrática do direito, enquanto que o substancialismo compreende que a atuação do juiz pode assumir uma postura ativa em reconhecimento da diretividade constitucional.

Nota-se, num encurtamento teórico, que o substancialismo valoriza os direitos; enquanto o procedimento, a forma. Neste sentido, o procedimentalismo imbrica forma e conteúdo e, embora valorize os processos discursivos e deliberativos, está também vinculado ao Estado de direito. O substancialismo, por sua vez, não despreza as formas. Inclusive, depende delas para assegurar a legalidade.

A discussão, desta maneira, não ocorre sobre o estabelecimento ou não de limites ao exercício da atividade jurisdicional, pois eles existem e variam. Discutiuse, então, uma área cinzenta a partir do julgamento proferido pelo Supremo Tribunal Federal, o qual foi responsável pela equiparação entre as uniões estáveis homoafetivas às constituídas por casais heterossexuais, já que a discussão somente a partir da teoria mostra-se insuficiente, tendo em vista que, ora a teoria discursiva confere melhores respostas, ora a teoria substancialista o faz.

Observou-se que ambas as teorias podem afirmar e justificar decisões semelhantes e, por isso, talvez uma boa forma de as diferenciar não seja pelos seus resultados, mas pelo risco que elas pretendem combater. Isso porque os substancialistas veem como risco para o processo democrático a formação 
de elites que podem afetar a formação do discurso democrático por meio do controle aos poderes Executivo e Legislativo, em virtude do deficit de direitos fundamentais dos países de modernidade tardia. Em contrapartida, a teoria discursiva habermasiana pondera que o risco à ordem democrática seria que essa mesma formação de elites impedisse o exercício democrático ao realizar o controle do Judiciário.

Para além da rotulação de uma decisão como "ativista", "comunistarista" ou "procedimentalista", o que deve servir de motivação à atuação judicial é a defesa dos direitos fundamentais somada à garantia da ordem democrática. Ou seja, não se pode transformar o Judiciário num legislador temporário, nem permitir que ele se abstenha de realizar a jurisdição constitucional, de forma a proporcionar a adequação do Direito como conjunto de normas à situação fática. É este equilíbrio, portanto, que deve ser extraído das teorias analisadas neste trabalho.

\section{REFERÊNCIAS DAS FONTES CITADAS}

BARBOSA, Estefânia Maria de Queiroz; KOZOCKI, Katya. Jurisdição constitucional brasileira: entre constitucionalismo e democracia. Revista Sequência, n. 56, p. 151-176, jun. 2008.

BRASIL. Supremo Tribunal Federal. Ação Direta de Inconstitucionalidade 4.274/DF. Relator: Min. Ayres Britto. Pleno. Brasília, 23.11.2011c. Disponível em: <http://redir.stf.jus.br/paginadorpub/ paginador.jsp?docTP=TP\&docID=1955301>. Acesso em: 30 jun. 2017.

. Ação Direta de Inconstitucionalidade 4.277. Disponível em: <http://redir.stf.jus. br/paginadorpub/paginador.jsp?docTP=AC\&docID=628635>. Acesso em: 10 jul. 2017.

. Supremo determina aplicação da lei de greve dos trabalhadores privados aos servidores públicos. Disponível em: <http://www.stf.jus.br/portal/cms/verNoticiaDetalhe. asp?idConteudo=75355>. Acesso em: 26 jun. 2017.

Supremo reconhece união homoafetiva. Disponível em: <http://www.stf.jus.br/ portal/cms/verNoticiaDetalhe.asp?idConteudo=178931>. Acesso em: 10 jul. 2017.

CHUERI, Vera Karam de; GODOY, Miguel. Constitucionalismo e Democracia - Soberania e Poder Constituinte. Revista DireitoGV, v. 6, n. 1, p. 159-174, jan.-jun., 2010.

CITTADINO, Gisele. Pluralismo, Direito e Justiça Distributiva: elementos da filosofia constitucional contemporânea. 2. ed. Rio de Janeiro: Lumen Juris, 2000. 
. Poder Judiciário, ativismo judicial e democracia. Revista da Faculdade de Direito de Campos, v. 2, n. 3, p. 135-144, 2002.

COSTA, Renata Pereira Carvalho; COURA, Alexandre de Castro. A atuação do magistrado e sua conformação paradigmática: o desafio de materializar o Estado Democrático de Direito, DPU, n. 32, p. 23-41, mar.-abril, 2010.

CRUZ, Álvaro Ricardo de Souza. Habermas e o direito brasileiro. 2. ed. Rio de Janeiro: Lumen Juris, 2008.

DWORKIN, Ronald. O Império do Direito. Tradução de Jeferson Luiz Camargo. 3. ed. São Paulo: Martins Fontes, 2014.

ESPINDOLA, Angela Araújo da Silveira; SANTOS, Igor Raatz dos. O processo civil no Estado democrático de direito e a releitura das garantias constitucionais: entre a passividade e o protagonismo judicial. Novos Estudos Jurídicos, v. 16, n. 2, p. 150-169, 2011.

HABERMAS, Jürgen. A inclusão do outro: estudos de teoria política. Tradução de George Sperber e Paulo Astor Soethe. São Paulo: Loyola, 2002.

Direito e democracia: entre facticidade e validade. 2. ed. v. II. Tradução de Flávio Beno Siebeneichler. Rio de Janeiro: Tempo Brasileiro, 1997.

KUHN, Thomas S. A estrutura das revoluções científicas. Tradução Beatriz Vianna Boeira e Nelson Boeira. 6. ed. São Paulo: Perspectiva, 2001.

MOREIRA, Nelson Camatta; TOVAR, Leonardo Zehuri. Ativismo judicial e resposta correta: análise crítica de fundamentos consequencialistas em Direito Tributário. Derecho y Cambio Social, v. 41, p. 1-16, 2015.

MOUFFE, Chantal. Pensando a democracia moderna com e contra Carl Schimitt. Cadernos da Escola do Legislativo. Tradução de Menelick de Carvalho Netto. Belo Horizonte, n. 02, p.01-14, jul./dez., 1994.

SOUZA NETO, Claudio Pereira de Souza; SARMENTO, Daniel. Controle de Constitucionalidade e Democracia: algumas teorias e parâmetros de ativismo. In: SARMENTO, Daniel (coord.). Jurisdição Constitucional e Política. Rio de Janeiro: Forense, 2015, p. 73-114.

STRECK, Lenio Luiz. Jurisdição Constitucional e Decisão Jurídica. São Paulo: Revista dos Tribunais, 2013.

.Jurisdição Constitucional e Hermenêutica: Perspectivas e Possibilidades de Concretização dos Direitos Fundamentais-Sociais no Brasil. Novos Estudos Jurídicos. v. 8, n. 2, p. 257-301, maio/ago. 2003. 
. Verdade e Consenso. Constituição, Hermenêutica e Teorias Discursivas. Da possiblidade à necessidade de respostas corretas em direito. 5. ed. São Paulo: Saraiva, 2014.

A atuação do judiciário em tempos de constitucionalismo contemporâneo: uma crítica ao ativismo judicial. Revista da Faculdade de Direito do Sul de Minas, Pouso Alegre, v. 28, n. 2, p. 31-46, jul./dez. 2012.

TASSINARI, Clarissa. Ativismo judicial: uma análise da atuação do Judiciário nas experiências brasileira e norte-americana. 2012. $141 \mathrm{fl}$. Dissertação (Mestrado em Direito na área das Ciências Jurídicas) - Universidade do Vale do Rio dos Sinos, São Leopoldo, 2012.

Recebido em: novembro/2017

Aprovado em: junho/2018 